\title{
A Study on College Students' Use Intention of Internet Learning Resources in Chongqing
}

\author{
Mao Chun ${ }^{1}$ \\ ${ }^{1}$ School of Journalism and Communication, Southwest University, Chongqing, China \\ Correspondence: Mao Chun, School of Journalism and Communication, Southwest University, Chongqing, \\ China. Tel: 86-132-1245-1814. E-mail: maochun1981@hotmail.com
}

Received: October 26, 2013 Accepted: December 15, 2013 Online Published: January 27, 2014

doi:10.5539/ass.v10n3p70

URL: http://dx.doi.org/10.5539/ass.v10n3p70

Supported by "the Fundamental Research Funds for the Central Universities" SWU0909655

\begin{abstract}
This paper imports Computer Self-Efficacy, Teacher's Support and Convenience to Use into Technology Acceptance Model (TAM), studies the factors of college students' use intention of Internet Learning Resources in Chongqing China. The primary research method is quantitative. There are 300 respondents have been selected among college students in Chongqing based on stratified sampling. The result based SPSS and AMOS indicates that students' use intention doesn't follow the TAM exactly. The influence of Perceived Ease of Use is not notability, while Perceived Usefulness and Teacher's Support have direct influence on Use Intention, and Computer Self-Efficacy has indirect influence on Use Intention.
\end{abstract}

Keywords: college students, internet learning resources, use intention, TAM

\section{Introduction}

With the advent of the information age, the application of information technology in educational field brings the innovation of education. Internet has been researched and employed as an important educational tool by teachers and researchers in many countries in recent years. In 2012, the Ministry of Education of the People's Republic of China released Education Informatization Ten Year Development Plan. The Plan claims that Informatization is an effective way to improve the quality of college education. According to The Plan, we should innovate college students' learning style based ICT.

Student is the main practitioner in the innovation of learning style. College students' use intention of Internet Learning Resources is the key of innovating learning style, and has an appreciable effect on the quality of education.

Chongqing is the fourth municipality directly under the Central authority in China. It's an extra large city in southwest of China, whose territory area is about 82,400 square kilometers, total population is 33,298,100. There are 63 colleges and universities in Chongqing.

This study is based on Technology Acceptance Model (TAM), proposes 7 hypotheses, constructs the model of college students' use intention of Internet Learning Resources, adopts the structure of close-ended questionnaire, surveys 4 colleges in Chongqing, hands out 300 questionnaires, adopts SPSS for reliability analysis and validity analysis, AMOS for model evaluation and validation, discusses the factors which impact college students' use intention of Internet Learning Resources in Chongqing.

\section{Theoretical Foundations and Hypotheses}

\subsection{Hypotheses Based on TAM}

Davis proposed "Technology Acceptance Model" (TAM) to predict and explain the use action of information systems (Davis, 1989). Davis' research put forward two key factors of information system use: Perceived Usefulness and Perceived Ease of Use. TAM emphasizes people are apt to use an information technology if they believe it will help them do a better job, the same if they believe the given system is easy to use. TAM has been proved to be a credible model in many researches (Stoel, 2003; Gong, 2004; Hua, 2008). This study believes that TAM can explain the acceptation and use of Internet Learning Resources among college students in Chongqing. 
According to Davis, we define Perceived Usefulness here as "the degree to which one believes that using the Internet Learning Resources would improve learning performance." Perceived Ease of Use is defined as "the degree one believes that using Internet Learning Resources would be free of difficulty or great effort." Based TAM, we get 4 hypotheses:

H: Perceived Usefulness is positive correlated with Use Intention of Internet Learning Resources

H: Perceived Ease of Use is positive correlated with Perceived Usefulness

H: Perceived Ease of Use is positive correlated with Use Intention of Internet Learning Resources

H: Convenience to Use is positive correlated with Perceived Ease of Use

\subsection{Hypotheses Based on Theory of Planned Behavior}

According to the theory of planned behavior, Subjective Norm is an independent determinant of intention. People's intention to perform a behavior is positive correlated with subjective norm (Ajzen, 1985). Generally accepted, subjective norm means the perceived pressure from others for performing a behavior or not. In our research, Subjective Norm mainly reflects in Teacher's Support. We defined it as the perceived encouragement and pressure of teacher about use or not to use the Internet Learning Resources. Based theory of planned behavior, we get 1 hypothesis:

H: Teacher's Support is positive correlated with Use Intention of Internet Learning Resources

\subsection{Hypotheses Based on Self-Efficacy}

Self-efficacy is an important factor of performance. It refers to a judgment of one's own capability to do a given work or perform a designated task (Bandura, 1986). Self-efficacy does not consider the skills one already has. It is concerned with one's judgments of own capability and what could be done in the future. Some of the researchers believe that the higher the one's computer self-efficacy, the lower her/his computer anxiety (Compeau, 1995; Chau, 2001). Computer self-efficacy refers to one's judgments of their own abilities of computer utilization. Almost all the Internet Learning Resources is used through computers. At present, every college offers courses of using computer to every student in Chongqing. So we assume that computer self-efficacy is positive correlated with Perceived Usefulness and Perceived Ease of Use. Computer self-efficacy does not emphasize single simple skills, such as typing words or chatting with Instant Messenger. It pays attention to judgments of the ability to fulfill a given task based those skills (such as preparing presentation with WPS or PowerPoint). Based social cognitive theory and self-efficacy, we get 2 hypotheses:

H: Computer Self-Efficacy is positive correlated with Perceived Ease of Use

H: Computer Self-Efficacy is positive correlated with Perceived Usefulness

\section{Research Model Based Hypotheses}

Based the 7 hypotheses proposed above, we construct the conceptual model of this research (Figure1). In this model, we assume that Perceived Ease of Use, Perceived Usefulness, and Teacher's Support have direct influence on Use Intention; Convenience to Use has direct influence on Perceived Ease of Use; Computer Self-Efficacy has direct influence on Perceived Ease of Use and Perceived Usefulness. 


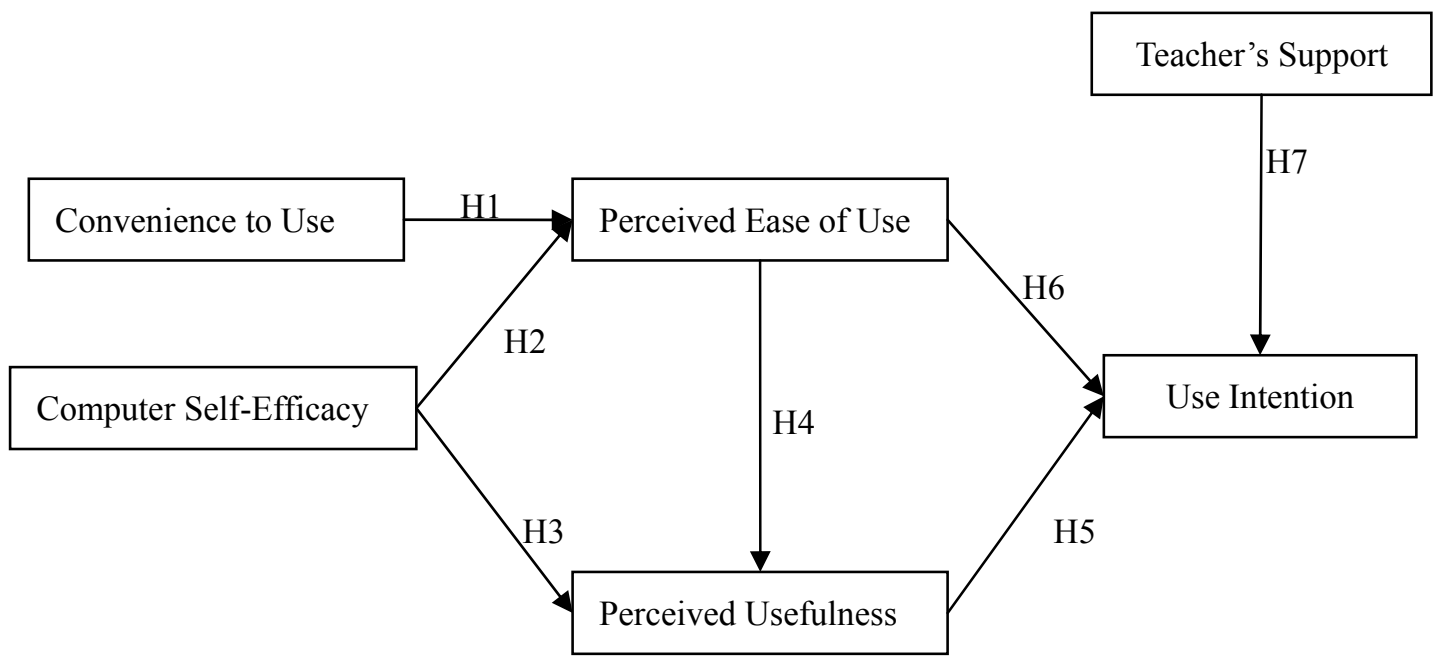

Figure 1. Conceptual model of the study

\section{Methodology}

This study adopts the structure of close-ended and the Likert-Scale five-point measure questionnaire. Each item is given a 5-point scale with $1=$ strongly disagree, $2=$ disagree, $3=$ slightly agree, $4=$ agree, and $5=$ strongly agree. Each questionnaire took 20-25 minutes to complete. The questionnaire was developed in Chinese. After we finished the original questionnaire, we sent the questionnaires to 30 students of southwest university in Chongqing for a preliminary investigation and analyzing the validity and reliability of the test paper. According to the results, we deleted some items, and revised statement of some items and layouts of the paper, and then we got the formal questionnaire in which 21 items were left. There were 3 items for Perceived Usefulness (PU), and 3 items for Perceived Ease of Use (PEU), 4 items for Computer Self-Efficacy (CSE), 3 items for Teacher's Support (TS), 4 items for Convenience to Use (CU), 3 items for Use Intention (UI) .The measure items were provided in the formal questionnaire as appendix.

Through stratified sampling, we chose 300 college students as the respondents. All of them came from 4 colleges in Chongqing: Southwest University, Chongqing Youth Vocational and Technical College, Chongqing University of Arts and Sciences, Chongqing College of Humanities, Science \& Technology. Data for the investigation were collected for 1 month. We hand out 75 questionnaires in each college, 4 colleges totally 300 questionnaires. Recall 287 questionnaires, 253 questionnaires were available.

\section{Data Analysis and Results}

\subsection{Descriptive Statistics}

There are 115 males and 138 females. The respondents for ways linking to internet are presented in Table 1, while for the time on the internet one day shown in Table 2.

Table 1. Respondents for ways linking to internet (multiple-choice)

\begin{tabular}{cccc}
\hline Ways & Self-Computer & Public Computer & Mobile Phone \\
\hline Number of People & 181 & 72 & 243 \\
\hline
\end{tabular}

Table 2. Respondents for time on the internet one day (single-choice)

\begin{tabular}{ccccccccc}
\hline Time(minute) & 0 & $1-30$ & $31-60$ & $61-90$ & $91-120$ & $121-150$ & $151-180$ & More than 180 \\
\hline Number of People & 0 & 12 & 85 & 71 & 44 & 25 & 9 & 7 \\
\hline
\end{tabular}

\subsection{Reliability and Validity Analysis}

We used SPSS 13 to analyze reliability and validity of the questionnaire. In Result of Reliability Analysis, CITC 
(Corrected Item-Total Correlation) of each Item is big than 0.5, and Cronbach's Alpha is big than 0.7. According to Anne M Smith, the internal consistency of items meets the reliability requirements (Smith, 1999). The result is shown in Table 3.

Table 3. Reliability of the research

\begin{tabular}{|c|c|c|c|c|}
\hline factor & item & CITC & Cronbach's Alpha if Item Deleted & Cronbach's Alpha \\
\hline \multirow{3}{*}{ Perceived Usefulness (PU) } & PU1 & 0.779 & 0.772 & \multirow{3}{*}{0.863} \\
\hline & PU2 & 0.707 & 0.843 & \\
\hline & PU3 & 0.750 & 0.800 & \\
\hline \multirow{3}{*}{ Perceived Ease of Use (PEU) } & PEOU1 & 0.654 & 0.904 & \multirow{3}{*}{0.869} \\
\hline & PEOU2 & 0.834 & 0.733 & \\
\hline & PEOU3 & 0.772 & 0.799 & \\
\hline \multirow{4}{*}{ Computer Self-Efficacy (CSE) } & CSE1 & 0.911 & 0.937 & \multirow{4}{*}{0.953} \\
\hline & CSE2 & 0.928 & 0.926 & \\
\hline & CSE3 & 0.920 & 0.928 & \\
\hline & CSE4 & 0.814 & 0.962 & \\
\hline \multirow{3}{*}{ Teacher’s Support (TS) } & SS1 & 0.613 & 0.540 & \multirow{3}{*}{0.719} \\
\hline & SS2 & 0.584 & 0.585 & \\
\hline & SS3 & 0.541 & 0.730 & \\
\hline \multirow{4}{*}{ Convenience to Use (CU) } & CU1 & 0.541 & 0.762 & \multirow{4}{*}{0.788} \\
\hline & CU2 & 0.629 & 0.720 & \\
\hline & CU3 & 0.680 & 0.692 & \\
\hline & CU4 & 0.546 & 0.766 & \\
\hline \multirow{3}{*}{ Use Intention (UI) } & UI1 & 0.883 & 0.858 & \multirow{3}{*}{0.923} \\
\hline & UI2 & 0.846 & 0.885 & \\
\hline & UI3 & 0.813 & 0.915 & \\
\hline
\end{tabular}

According to Fornell's research (Fornell, 1981), convergent validity must come up to three standards: (1) Factor loading $>0.5$; (2) Composite reliability (CR) $>0.8$; (3) Average variance extracted (AVE) $>0.5$. In our investigation, the data meets the convergent validity. The result is shown in Table 4. 
Table 4. Convergent validity of the research

\begin{tabular}{|c|c|c|c|c|}
\hline factor & item & $\begin{array}{l}\text { Factor } \\
\text { loading }\end{array}$ & $\begin{array}{l}\text { Composite reliability } \\
\text { (CR) }\end{array}$ & $\begin{array}{c}\text { Average variance extracted } \\
\text { (AVE) }\end{array}$ \\
\hline \multirow{3}{*}{ Perceived Usefulness (PU) } & PU1 & 0.846 & 0.876 & 0.703 \\
\hline & PU2 & 0.900 & & \\
\hline & PU3 & 0.711 & & \\
\hline \multirow{3}{*}{$\begin{array}{l}\text { Perceived Ease of Use } \\
\text { (PEU) }\end{array}$} & PEU1 & 0.875 & 0.819 & 0.605 \\
\hline & PEU2 & 0.877 & & \\
\hline & PEU3 & 0.665 & & \\
\hline \multirow{4}{*}{$\begin{array}{l}\text { Computer Self-Efficacy } \\
\text { (CSE) }\end{array}$} & CSE1 & 0.893 & 0.921 & 0.746 \\
\hline & CSE2 & 0.901 & & \\
\hline & CSE3 & 0.871 & & \\
\hline & CSE4 & 0.855 & & \\
\hline \multirow{3}{*}{ Teacher's Support (TS) } & TS1 & 0.717 & 0.810 & 0.602 \\
\hline & TS2 & 0.616 & & \\
\hline & TS3 & 0.763 & & \\
\hline \multirow{4}{*}{ Convenience to Use (CU) } & CU1 & 0.818 & 0.842 & 0.575 \\
\hline & CU2 & 0.948 & & \\
\hline & CU3 & 0.748 & & \\
\hline & CU4 & 0.674 & & \\
\hline \multirow{3}{*}{ Use Intention (UI) } & UI1 & 0.807 & 0.884 & 0.703 \\
\hline & UI2 & 0.876 & & \\
\hline & UI3 & 0.812 & & \\
\hline
\end{tabular}

\subsection{Model Evaluation and Explanation}

In order to evaluation the model shown in Figure 1, it is essential to examine the goodness of fit between model and data. We use AMOS17.0 to implement structural equation analysis, all fit indexes shown in table 5.

Table 5. Fit indexes of the model

\begin{tabular}{lcc}
\hline \multicolumn{1}{c}{ Fit Index } & Recommended Value & The Model's Value \\
\hline$\chi^{2} / \mathrm{df}$ & $2 \sim 5$ & 2.897 \\
Normal Fit Index (NFI) & $>.9$ & .877 \\
Incremental Fit Index (IFI) & $>.9$ & .905 \\
Comparative Fit Index (CFI) & $>.9$ & .942 \\
Goodness-of-Fit Index (GFI) & $>.8$ & .812 \\
Ajusted Goodness-of-Fit Index (AGFI) & $>.8$ & .787 \\
Root mean square error of approximation (RMSEA) & $<.1$ & .090 \\
\hline
\end{tabular}

According to table 4, fit indexes of the model are almost meet the requirement, in other word, the model can be used to verify hypothesis.

5.4 Results

Based AMOS, we get figure 2, which shows completely standardized path coefficient within Latent Variables of the Model. 


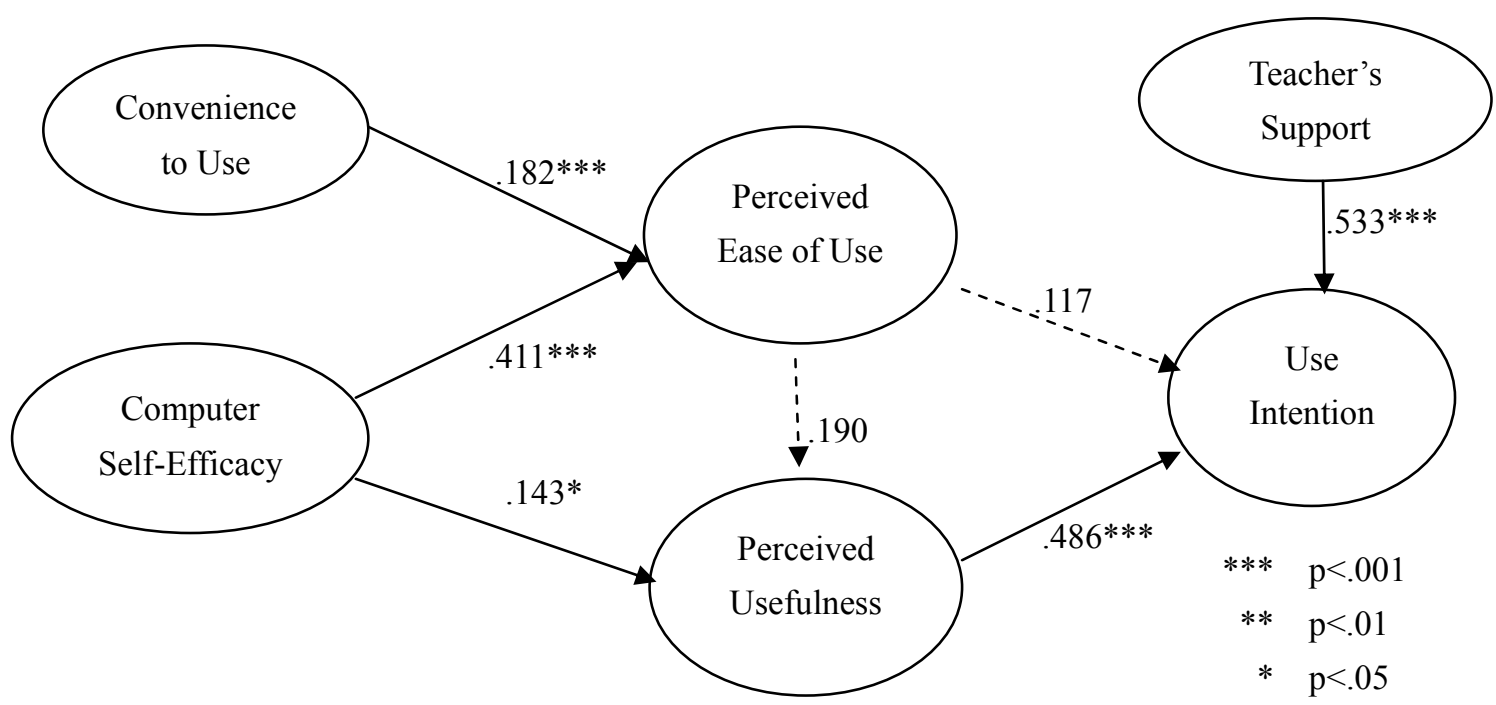

Figure 2. Completely standardized path coefficient within latent variables of the model

According to figure 2, the results of the hypothesis verification follow in table 4 .

Table 6. Results of the hypothesis verification

\begin{tabular}{lc}
\hline \multicolumn{1}{c}{ Hypothesis } & Result \\
\hline H1: Convenience to Use is positive correlated with Perceived Ease of Use & YES \\
H2: Computer Self-Efficacy is positive correlated with Perceived Ease of Use & YES \\
H3: Computer Self-Efficacy is positive correlated with Perceived Usefulness & YES \\
H4: Perceived Ease of Use is positive correlated with Perceived Usefulness & NO \\
H5: Perceived Usefulness is positive correlated with Use Intention of Internet Learning Resources & YES \\
H6: Perceived Ease of Use is positive correlated with Use Intention of Internet Learning Resources & NO \\
H7: Teacher's Support is positive correlated with Use Intention of Internet Learning Resources & YES \\
\hline
\end{tabular}

\subsection{Discussion}

Based on the results obtained above, there are 3 factors affect students' use intention of internet learning resources among colleges and universities in Chongqing, include Teacher's Support, Perceived Usefulness and Computer Self-Efficacy. Teacher's Support and Perceived Usefulness have direct influence on Use Intention, and Computer Self-Efficacy has indirect influence on Use Intention.

The influence of teacher's support is a major factor in using internet learning resources among college students. This may be based on the fact that classroom teaching is the most important learning activity in colleges, and teachers have a major role in students' performance.

Perceived usefulness is another major factor which can influence the use intention of internet learning resources among college students. Almost all the teachers and students be asked said that if the resources cannot improve learning, they would not use it. This is consistent with past studies (Stoel, 2003; Gong, 2004).

Meanwhile, the influence of perceived ease of use is not notability in using internet learning resources among college students. The main reason may be is that all the college students are good at computer using; also it is easy to link to internet and surf on the internet.

\section{Conclusions}

It is information era. It is cheering that the Chinese government has been investing more and more money into education Informatization. We should develop learning websites based on the need of college students; encourage students using ICT and internet learning resources to improve performance; share various learning resources to teachers and students. 


\section{References}

Ajzen, I. (1985). From intentions to actions: A theory of planned behavior. In J. Kuhl, \& J. Beckman (Eds.), Action control: From cognition to behavior (pp. 11-39). Heidelberg: Springer. http://dx.doi.org/10.1007/978-3-642-69746-3_2

Bandura, A. (1986). Social foundations of thought and action: A social cognitive theory. Englewood Cliffs, NJ: Prentice Hall.

Chau, P. Y. (2001). Influence of computer attitude and self-efficacy on IT usage behavior. Journal of End User Computing, 13, 26-33. http://dx.doi.org/10.4018/joeuc.2001010103

Chen, Y. (2005). The usage of technology acceptance model in web based education. The Chinese Journal of ICT in Education, 2, 72-73.

Compeau, D., \& Higgins, C. (1995). Computer self-efficacy: Development of a measure and initial test. MIS Quarterly, 19, 189-211. http://dx.doi.org/10.2307/249688

Davis, F. D. (1989). Perceived usefulness, perceived ease of use, and user acceptance of information technology. MIS Quarterly, 13, 319-340. http://dx.doi.org/10.2307/249008

Fornell, C., \& Larcker, D. F. (1981). Structural Equation Model with Unobservable Variables and Measurement Error: Algebra and statistics. Journal of Marketing Research, 18(3), 382-389. http://dx.doi.org/10.2307/3150980

Gong, M., Xu, Y., \& Yu, Y. C. (2004). An enhanced technology acceptance model for web-based learning. Journal of Information Systems Education, 15, 365-374.

Hua, Y. D. (2008). Using TAM to explore children's Moodle learning behavior-taking an issue of computing education as example. Taichung: TungHai University.

Smith, A. M. (1999). Some problems when adopting Churchill's Paradigm for the development of service quality measurement scales. Journal of Business Research, 46, 109-120. http://dx.doi.org/10.1016/S0148-2963(98)00015-0

Stoel, L., \& Lee, K. H. (2003). Modeling the effect of experience on student acceptance of web-based courseware. Internet Research, 13, 364-374. http://dx.doi.org/10.1108/10662240310501649

\section{Appendix}

Questionnaire of students' Use Intention of Internet Learning Resources

This questionnaire is only for understanding of use intention of internet learning resources of contemporary college students. This questionnaire survey is absolutely anonymous. Thanks for your participation, thank you!

\section{Part one: Basic information}

1. Your gender: (A) female [ ]

(B) male [ ]

2. Ways linking to internet (multiple check):
(A) Self-Computer [ ]
(B) public computer [ ]
(C) Mobile Phone [ ]

3. How much the time you spend on the internet one day (minutes)? (Check only one)
(A) 0 minute [ ]
(B) 1-30 minutes [ ]
(C) 31-60 minutes [ ]
(D) 61-90 minutes [ ]
(E) 91-120 minutes [ ]
(F) 121-150 minutes [ ]
(G) 151-180 minutes [ ]
(H) more than 180 minutes [ ]

4. Have you been use internet learning resources before? (Check only one)
(A) yes [ ]
(B) no [ ] 
Part two: Factors of use intention (Check only one)

$[1]=$ strongly disagree, $[2]=$ disagree, $[3]=$ slightly agree, $[4]=$ agree, $[5]=$ strongly agree

\section{Perceived Usefulness}

1. Internet learning resources can improve my learning efficiency.

2. Internet learning resources can improve my learning method.

3. Internet learning resources can improve my course grade.

\section{Perceived Ease of Use}

1. Using internet learning resources is very easy.

2. It is very easy to use internet learning resources in campus.

3. In my study, using internet learning resources is very easy.

\section{Computer Self-Efficacy}

1. I believe that I can use computer and surf on the internet freely.

2. I believe that I can use email and QQ freely.

3. I believe that I can search and find internet learning resources freely.

4. I believe that I can process documents and images by computer freely.

\section{Teacher's Support}

1. Teacher has been given me internet learning resources or websites.

2. Teacher encourages me use internet learning resources.

3. Teacher has been assigned works or tasks finished through internet.

\section{Convenience to Use}

1. The net speed is good for using internet learning resources.

2. The hardware (such as computer or mobile phone) is convenient when I need to surf on the internet.

3. There are a lot of learning resources on the internet.

4. It is convenient to use internet learning resources for learning.

\begin{tabular}{|c|c|c|c|c|}
\hline $\begin{array}{l}\text { strongly } \\
\text { disagree }\end{array}$ & disagree & $\begin{array}{c}\text { slightly } \\
\text { agree }\end{array}$ & agree & $\begin{array}{c}\text { strongly } \\
\text { agree }\end{array}$ \\
\hline [1] & [2] & [3] & [4] & [5] \\
\hline [1] & [2] & [3] & [4] & [5] \\
\hline [1] & [2] & [3] & [4] & [5] \\
\hline $\begin{array}{l}\text { strongly } \\
\text { disagree }\end{array}$ & disagree & $\begin{array}{c}\text { slightly } \\
\text { agree }\end{array}$ & agree & $\begin{array}{c}\text { strongly } \\
\text { agree }\end{array}$ \\
\hline [1] & [2] & [3] & [4] & [5] \\
\hline [1] & [2] & [3] & [4] & [5] \\
\hline [1] & [2] & [3] & [4] & [5] \\
\hline $\begin{array}{l}\text { strongly } \\
\text { disagree }\end{array}$ & disagree & $\begin{array}{c}\text { slightly } \\
\text { agree }\end{array}$ & agree & $\begin{array}{c}\text { strongly } \\
\text { agree }\end{array}$ \\
\hline [1] & [2] & [3] & [4] & [5] \\
\hline [1] & [2] & [3] & [4] & [5] \\
\hline [1] & [2] & [3] & [4] & [5] \\
\hline [1] & [2] & [3] & [4] & [5] \\
\hline $\begin{array}{l}\text { strongly } \\
\text { disagree }\end{array}$ & disagree & $\begin{array}{c}\text { slightly } \\
\text { agree }\end{array}$ & agree & $\begin{array}{c}\text { strongly } \\
\text { agree }\end{array}$ \\
\hline [1] & [2] & [3] & [4] & [5] \\
\hline [1] & [2] & [3] & [4] & [5] \\
\hline [1] & [2] & [3] & [4] & [5] \\
\hline $\begin{array}{l}\text { strongly } \\
\text { disagree }\end{array}$ & disagree & $\begin{array}{c}\text { slightly } \\
\text { agree }\end{array}$ & agree & $\begin{array}{c}\text { strongly } \\
\text { agree }\end{array}$ \\
\hline
\end{tabular}

$[1] \quad[2] \quad[3] \quad[4] \quad[5]$

$[1] \quad[2] \quad[3] \quad[4] \quad[5]$

$[1] \quad[2] \quad[3] \quad[4] \quad[5]$

$[1] \quad[2] \quad[3] \quad[4] \quad[5]$ 


\section{Use Intention}

$\begin{array}{ccccc}\text { strongly } & \text { disagree } & \begin{array}{c}\text { slightly } \\ \text { agree }\end{array} & \text { agree } & \text { strongly } \\ \text { disagree } & & \text { agree }\end{array}$

1. I intend to use or keep on using internet learning resources.

\section{[1]}

[1]

[1]
[2]

[3]

[4]

$[5]$

2. I'm glad to try more ways of using internet learning resources.

3. I'm glad to use internet learning resources regularly.

[2] [3] [4]

$[2] \quad[3] \quad[4]$

$[5]$

[5]

\section{Copyrights}

Copyright for this article is retained by the author(s), with first publication rights granted to the journal.

This is an open-access article distributed under the terms and conditions of the Creative Commons Attribution license (http://creativecommons.org/licenses/by/3.0/). 